\title{
Determination of Aflatoxin M1 and Ochratoxin A in Milk and Dairy Products in Supermarkets Located in Mansoura City, Egypt
}

\author{
Gamal Younis ${ }^{1}$, Dina Ibrahim ${ }^{1}$, Amal Awad ${ }^{1 *}$, Mohamed Makin El Bardisy ${ }^{2}$
}

\author{
${ }^{1}$ Department of Bacteriology, Mycology and Immunology, Faculty of Veterinary Medicine, Mansoura University, \\ Mansoura, 35516, Egypt; ${ }^{2}$ Animal Health Research Institute, Dokki, Egypt.
}

\begin{abstract}
In this study, the occurrence of different mould species from milk samples, milk powder, roomy cheese and kariesh cheese samples in Mansoura city, Egypt was determined. Out of 200 randomly screened samples, 67(33.5\%) were confirmed positive for the presence of different mould species. The overall incidence rate in raw milk, milk powder, roomy cheese and kariesh cheese were $20 \%, 38 \%, 48 \%$ and $28 \%$ respectively with a mean mould counts, $2.284 \pm$ $0.488 \times 10^{2} \mathrm{cfu} / \mathrm{mL}, 1.416 \pm 0.155 \times 10^{2} \mathrm{cfu} / \mathrm{g}, 2.727 \pm 0.770 \times 10^{2} \mathrm{cfu} / \mathrm{g}$ and $1.950 \pm 0.578 \times 10^{2} \mathrm{cfu} / \mathrm{gmL}$ respectively Significant variation in the incidence of different mould species was detected among different examined samples. Various mould species were recovered from these examined samples including, Aspergillus spp., Penicillium spp., Mucor spp., Geotrichum spp., Cladosporium spp., Byssochlamys spp., Nigrospora spp., Rhizopus spp., Acremonium spp., Fusarium spp. and Paecilomyces spp. Aflatoxin M1 (AFM1) and Ochratoxin A (OTA) were estimated in a total of 40 raw milk and dairy products samples by immunoaffinity column (IAC) and was measured by VICAM fluorometer. AFM1 was detected in $70 \%$ of all examined samples, while; OTA was detected in $\% 80$ of all examined samples. A significant difference between concentrations of OTA ( $p=0.037)$ and concentrations of AFM1 $(p=0.001)$ among different milk products were detected. All positive samples harboring AFM1 exceeded the Egyptian regulation for AFM1 in milk. In conclusion, Presence of moulds and mycotoxins in milk and different dairy products with high percentage indicates public health hazards that require strict hygienic conditions in dairy products industry.
\end{abstract}

Keywords | Moulds, Dairy products, Mycotoxins, Aflatoxin M1, Ochratoxin A

Editor $\mid$ Kuldeep Dhama, Indian Veterinary Research Institute, Uttar Pradesh, India.

Received | December 04, 2015; Revised | January 06, 2016; Accepted | January 08, 2016; Published | February 25, 2016

*Correspondence | Amal Awad, Mansoura University, Mansoura, Egypt; Email: dr_amalvet@yahoo.com, amalabdo@mans.edu.eg

Citation | Younis G, Ibrahim D, Awad A, El Bardisy MM (2016). Determination of aflatoxin M1 and ochratoxin A in milk and dairy products in supermarkets located in Mansoura City, Egypt. Adv. Anim. Vet. Sci. 4(2): 114-121.

DOI | http://dx.doi.org/10.14737/journal.aavs/2016/4.2.114.121

ISSN (Online) | 2307-8316; ISSN (Print) | 2309-3331

Copyright (C) 2016 Younis et al. This is an open access article distributed under the Creative Commons Attribution License, which permits unrestricted use, distribution, and reproduction in any medium, provided the original work is properly cited.

$\mathrm{M}$ ilk and its products are being nutritious food for human and they provide a favorable environment for the growth of various microorganisms. Yeast and moulds can grow in milk and different dairy products at suitable conditions of temperature and moisture (Barrois et al., 1997). Mycotoxins are secondary metabolites of low molecular weight produced by naturally occurring fungi in different kinds of foods and feed stuffs, particularly cereals, peanut, meat, meat products, milk, milk products or eggs (Brown et al., 2001). Mycotoxins can be found in dairy products from two origins, indirect contamination, which results when dairy cows ingest feed that contains mycotoxins which pass into the milk such as aflatoxin $M_{1}$ and direct contamination, which results from accidental growth of moulds secreting aflatoxins. (Sengun et al., 2008). Fungal metabolites have toxic effects when present in foods, their effects range from acute (for example, liver or kidney deterioration), to chronic (for example, liver cancer), mutagenic, and teratogenic; and resulting symptoms range from skin irritation to immunosuppression, birth defects, neurotoxicity or death (ICMSF, 1996). Mycotoxins have many economic impacts including reduced livestock production, increased health care and veterinary care costs, disposal of contaminated foods and feeds, and investment in research and applications to reduce severity of the mycotoxin problem (Zain, 2011). There are many mycotoxins of worldwide public health importance including, Aflatoxins, ochratoxins (OAs), fumonisins, zearalenone 
(ZEN), and trichothecenes (FAO, 2001). Aflatoxins are a group of toxic compounds produced by certain strains of Aspergillus flavus, Aspergillus parasiticus and rarely Aspergillus nomius (Van Egmond, 1989; Creppy, 2002). The major aflatoxins are called B1, B2, G1, and G2 (based on their fluorescence under UV light (blue or green) M1 and M2 (produced in milk and dairy products) (D'Mello and MacDonald, 1997). Aflatoxin M1 (AFM1) may be found in the milk of animals that are fed on aflatoxin B1 (AFB1) containing feed (Van Egmond, 1991). Ochratoxin $\mathrm{A}$ (OTA) is a mycotoxin produced by different species of Aspergillus (A. ochraceus, A. melleus, A. sulphureus, A. Niger, A. carbonarius, A. awamori) and Penicillium (P. verrucosum, P. crysogenum and P. nordicum) (Bayman and Baker, 2006; Magan, 2006; Zheng et al., 2005). Ochratoxin $\mathrm{A}$ has hepatotoxic, nephrotoxic and teratogenic effects (Boudra and Morgavi, 2006). OTA has been classified by the International Agency of Research in Cancer (IARC) as a carcinogenetic of 2B class (Muscarella et al., 2004). Mycotoxin analysis in food and feed is generally a multi-step process comprised of sampling, sample preparation, toxin extraction from the matrix (usually with mixtures of water and polar organic solvents), extract clean up and finally detection and quantitative determination (Koppen et al., 2010). In Egypt, the data concerning mycotoxins contamination in foods, especially aflatoxin M1 and ochratoxin A from dairy products, are lacking and these collected data are the first step for prevention and control of mycotoxins hazard. This study, therefore, was conducted to determine the prevalence of different mould species in milk and dairy products from different supermarkets located in Mansoura city, Egypt, with estimation of mycotoxins in the examined samples including, AFM1, OTA and to compare their levels with the permissible limits if founded.

A total of 200 samples of raw milk, milk powder, roomy cheese and kariesh cheese (50 each) were collected randomly from different supermarkets located in Mansoura city, Egypt. The collected samples were transferred directly to the laboratory with a minimum of delay under a septic condition. Each sample was divided into two parts. The first part was prepared for mycological examination and the second one was kept frozen for mycotoxins estimation. Preparation of samples for mycological examination was done according to (APHA, 1992).

For Fungal isolation and identification, $100 \mu \mathrm{L}$ from each sample were spread onto plate of Sabouraud dextrose agar (SDA) medium by using a bent sterile glass spreader rod (hockey stick). The inoculated plates were incubated at $25^{\circ} \mathrm{C}$ for 5-7 days and examined daily (Pitt et al., 1992). Mould count in each plate was recorded after 48 hours of incubation. Moulds identification was done according to Pitt and Hocking (1997).
AFM1 estimation in milk and dairy products samples including, samples preparation, toxin extraction, clean up via $\mathrm{IAC}$, toxin elution and measure with Vicam flourometry were done following the Vicam AFM1-FL+\4.2 -GNMC9954-4. $40 \mathrm{~mL}$ of raw milk samples were centrifuged at $2000 \mathrm{X} \mathrm{g}$ for $10 \mathrm{~min}$, bottom layer (skimmed part) was carefully collected for analysis. $10 \mathrm{~g}$ of milk powder samples were reconstituted with $100 \mathrm{~mL}$ of preheated purified water gradually until a homogeneous mixture was obtained; $40 \mathrm{~mL}$ of reconstituted milk was used as raw milk samples. Concerning to the kariesh cheese samples, $10 \mathrm{gm}$ of samples were homogenized with $100 \mathrm{~mL}$ distilled water then $40 \mathrm{~mL}$ of homogenized sample was used as raw milk samples. Preparation of roomy cheese was done according to (AOAC 991.31, 1991), 25 gm of roomy cheese samples were mixed with $5 \mathrm{~g}$ of $\mathrm{Nacl}$ and blended with $125 \mathrm{~mL}$ methanol:water (70:30) at high speed for 2 minutes. The extract was filtered through a fluted filter paper. $15 \mathrm{~mL}$ of the filtered extract was diluted with $30 \mathrm{~mL}$ distilled water, then filtered through $1.5 \mu \mathrm{m}$ glass microfibre filter. $15 \mathrm{~mL}$ of the filtered extract $(15 \mathrm{~mL}=1.0 \mathrm{~g}$ sample equivalent $)$ was used for analysis. The final extract of each sample was passed through IAC (Vicam Afla M1 FL+ Column, Vicam, Watertown, MA, USA) completely at a rate of 1-2 drops/second until air came through column. Column was washed twice using $10 \mathrm{~mL}$ of washing solution. Toxin was eluted using $1 \mathrm{~mL}$ methanol (HPLC grade) a rate of $1 \mathrm{drop} /$ second until air came through column and all of the sample was eluated $(1.0 \mathrm{~mL})$ and collected in a glass cuvette. One $\mathrm{mL}$ diluted AflaTest Developer was added to the elute in the cuvette and mixed well, then placed in a calibrated fluorometer (VICAM Series 4,4EX, MA, USA).

For Ochratoxin A estimation in raw milk and milk products, Milk samples were prepared according to Iha et al. (2014). $10 \mathrm{~g}$ of each milk powder sample was reconstituted with $100 \mathrm{~mL}$ of preheated purified water gradually until a homogeneous mixture was obtained and then used as raw milk samples. Preparation of cheese samples according to Scott (2002), $25 \mathrm{gm}$ of sample was mixed with extraction solvent (methanol) and aqueous sodium bicarbonate followed by high speed blending. The extract was filtered through fluted filter paper. The diluted extract was filtered through $1.5 \mu \mathrm{m}$ glass microfibre filter then directly passed through IAC (Vicam Ochratest affinity column, Vicam, watertown, MA, USA) according to

Data were analysed by using SPSS, 2004 (version 16.0). Chi square test was used to test association between incidences of different mould count in milk products, also analysis of difference in a concentration of different toxin in milk products at $\mathrm{p}$-value $<0.05$.

A total of 200 samples including raw milk, milk powder, 
roomy cheese and kariesh cheese (50 each) were evaluated mycologically, Moulds were detected in 67(33.5\%) of the examined samples. Mould incidence rates in raw milk, milk powder, roomy cheese and karish cheese were $10(20 \%)$, 19 (38\%), 24 (48\%) and 14(28\%), respectively (Table 1). Statistical analysis showed significant difference between different examined samples in the prevalence of mould species ( $\mathrm{p}$ value $=0.0191$ ). Roomy cheese samples showed the highest prevalence of moulds $(48 \%)$ and the highest mean mould count $\left(2.727 \pm 0.770 \times 10^{2} \mathrm{cfu} / \mathrm{g}\right)$, the source of this high contamination of cheese may be raw materials as milk, starter culture and brine, air, water, equipments, workers walls and shelves of ripening room, etc. (Chapman and Sharpe, 1990).

Table 1: The mean mould counts in different examined samples

\begin{tabular}{lllllll|}
\hline Samples & $\begin{array}{l}\text { Exam- } \\
\text { ined } \\
\text { samples }\end{array}$ & \multicolumn{2}{l}{$\begin{array}{l}\text { Positive } \\
\text { samples }\end{array}$} & \multicolumn{2}{l}{ Mould count cfu/g or mL } \\
& No. & $\%$ & Min & Max & Mean \pm SE \\
\hline Raw milk & 50 & 10 & 20 & $1 \times 10^{2}$ & $6 \times 10^{2}$ & $2.28 \pm 0.49$ \\
\hline $\begin{array}{l}\text { Milk } \\
\text { powder }\end{array}$ & 50 & 19 & 38 & $1 \times 10^{2}$ & $2 \times 10^{2}$ & $1.42 \pm 0.16$ \\
\hline $\begin{array}{l}\text { Roomy } \\
\text { cheese }\end{array}$ & 50 & 24 & 48 & $1 \times 10^{2}$ & $8 \times 10^{2}$ & $2.73 \pm 0.77$ \\
\hline $\begin{array}{l}\text { Kariesh } \\
\text { cheese }\end{array}$ & 50 & 14 & 28 & $1 \times 10^{2}$ & $6 \times 10^{2}$ & $1.95 \pm 0.58$ \\
\hline \begin{tabular}{l} 
Total \\
\hline
\end{tabular} & 200 & 67 & 33.5 & $1 \times 10^{2}$ & $8 \times 10^{2}$ & $2.08 \pm 0.29$ \\
\hline
\end{tabular}

Aspergillus niger, A. flavus, A.terreus, A.versicolor and A. oryzae were isolated from the examined raw milk samples, A.niger was the predominant species. Statistical analysis showed a high significant difference in the prevalence of mould species in the examined raw milk samples $(p=0.0026)$. Wide distribution of mould spores in the unsanitized environment considers the main cause for milk contamination during milk production, transportation and/ or storage (Bullerman, 1979; Samson et al.,1988). Mould count in the examined raw milk samples was ranged from $1 \times 10^{2}$ to $6 \times 10^{2} \mathrm{cfu} / \mathrm{mL}$ with a mean $\pm \mathrm{SE}$ value of $2.284 \pm$ $0.488 \times 10^{2} \mathrm{cfu} / \mathrm{mL}$ (Table 1 ). These results are higher than (Desmasures et al., 1997) and (Bille et al., 2009) and lower than (Tasci, 2011).

Concerning to milk powder samples, out of 50 examined samples, 19(38\%) samples were contaminated with different mould species including, A.flavus, A.niger, P.chrysogenum, P. funiculosum and P.corylophilum, Paecilomyces spp., Cladosporium spp., Nigrospora spp. and Rhizopus spp. Statistical analysis showed no significant difference in the prevalence of mould species in the examined milk powder samples. Presence of moulds in milk powder may be resulted from contaminated air, bad environment in some factories as dispersed milk powder on ground, equipments, work- ers' clothes which promote growth of micro-organisms, uncontrolled sterilization, reinfection after pasteurization (Bonfoth, 2004) or use of low quality milk, utensils during stage of production, processing, transportion or storage. (Cross, 1997). Mould count in the examined milk powder samples was ranged from $1 \times 10^{2}$ to $2 \times 10^{2} \mathrm{cfu} / \mathrm{g}$ with a mean $\pm \mathrm{SE}$ value of $1.416 \pm 0.155 \times 10^{2} \mathrm{cfu} / \mathrm{g}$. this count exceeded the Egyptian permissibile limit which should not exceed $10 \mathrm{cfu} / \mathrm{g}$ (Egyptian standards, 1648/2005) which has a high risk on human health.

Out of 50 hard (roomy) cheese samples, (24) 48\% were contaminated with different species of moulds (Table 1). A.parasiticus A.niger A.terreus, A.fumigatus, P.oxalicum, P. cyclopium, Cladosporium spp., Byssochlamys spp. and Geotrichum spp. were detected in the examined samples; A.niger was the predominant species (Table 2). Statistical analysis showed a high significant difference in the incidence of mould species in the examined roomy cheese samples $(\mathrm{p}=0.0005)$. These results are nearly similar to Sabreen and Zaky (2001) and EL-fadaly et al. (2015). Mould count in the examined roomy cheese samples ranged from $1 \times 10^{2}$ to $8 \times 10^{2} \mathrm{cfu} / \mathrm{g}$ with a mean $\pm \mathrm{SE}$ value of $2.727 \pm 0.770 \times 10^{2}$ cfu/g. which exceeded the Egyptian permissible limit for presence of moulds in hard cheese according to the Egyptian standards 1007/2005 (not exceed $10 \mathrm{cfu} / \mathrm{g}$ ).

In this study, a total of 50 soft (kariesh) cheese samples were evaluated for the presence of mould species, Different mould species were isolated including Geotrichum spp., A.flavus, A.niger, Mucor spp., Fusarium spp. and Acremonium spp.. Geotrichum spp. was the predominant species in the positive samples (Table 2). Statistical analysis showed that a high significant difference was detected in the incidence of mould species in the examined kariesh cheese samples $(\mathrm{p}=0.002)$. These results are nearly similar to El-Diasty and Salem (2008) and with Sabreen and Zaky (2001). Mould count in the examined kariesh cheese samples was ranged from $1 \times 10^{2}$ to $6 \times 10^{2} \mathrm{cfu} / \mathrm{g}$ with a mean $\pm \mathrm{SE}$ value of 1.95 $\pm 0.578 \times 10^{2} \mathrm{cfu} / \mathrm{g}$ which exceeded the Egyptian permissible limit (not exceed $10 \mathrm{cfu} / \mathrm{g}$ ) according to the Egyptian standards 1008/2005.Mould contamination may represent a great hazard even in small counts if the package is opened and kept under uncontrolled temperature and moisture conditions which activate mould to produce toxins (El-Shazly, 2002) so the viable counts of moulds are not a reliable indicator of mycotoxin production (Pitt, 1984).

Presence of moulds as Aspergillus or Penicillium genera didn't indicate presence of their mycotoxins in dairy products due to some strains are non-toxigenic or even toxigenic strains didn't produce their toxins (Zerfiridis, 1985). While presence of mycotoxin in foods and feed depend on environmental conditions related to storage and other $\mathrm{ex}^{-}$ trinsic factors as climate or intrinsic factors such as fungal 
Table 2: Mould genera recovered from the examined samples

\begin{tabular}{|c|c|c|c|c|c|c|c|c|}
\hline \multirow[t]{3}{*}{ Moulds } & \multicolumn{8}{|c|}{ Positive Samples } \\
\hline & \multicolumn{2}{|c|}{ Raw milk } & \multicolumn{2}{|c|}{ Milk powder } & \multicolumn{2}{|c|}{ Kariesh cheese } & \multicolumn{2}{|c|}{ Roomy cheese } \\
\hline & No. & $\%$ & No & $\%$ & No & $\%$ & No. & $\%$ \\
\hline A.niger & 7 & 63.63 & 4 & 21 & 1 & 6.66 & 10 & 33.33 \\
\hline A.flavus & 1 & 9 & 2 & 10.52 & 1 & 6.66 & - & - \\
\hline A.parasiticus & - & - & - & - & - & - & 7 & 23.33 \\
\hline A.terreus & 1 & 9 & - & - & - & - & 4 & 13.33 \\
\hline A.oryzae & 1 & 9 & - & - & - & - & - & - \\
\hline A.fumigatus & - & - & - & - & - & - & 1 & 3.33 \\
\hline A.versicolor & 1 & 9 & - & - & - & - & - & - \\
\hline Paecilomyces spp. & - & - & 1 & 5.26 & - & - & - & - \\
\hline P.chrysogenum & - & - & 3 & 15.78 & - & - & - & - \\
\hline P.funiculosum & - & - & 2 & 10.52 & - & - & - & - \\
\hline P.corylophilum & - & - & 1 & 5.26 & - & - & - & - \\
\hline P.oxalicum & - & - & - & - & - & - & 1 & 3.33 \\
\hline P.cyclopium & - & - & - & - & - & - & 1 & 3.33 \\
\hline Cladosporium spp. & - & - & 4 & 21 & - & - & 2 & 6.66 \\
\hline Nigrosporia spp. & - & - & 1 & 5.26 & - & - & - & - \\
\hline Rhizopus spp. & - & - & 1 & 5.26 & - & - & - & - \\
\hline Byssochlamys spp. & - & - & - & - & - & - & 3 & 10 \\
\hline Mucor spp. & - & - & - & - & 3 & 20 & - & - \\
\hline Acremonium spp. & - & - & - & - & 1 & 6.66 & - & - \\
\hline Fusarium spp. & - & - & - & - & 1 & 6.66 & - & - \\
\hline Geotrichum spp. & - & - & - & - & 8 & 53.33 & 1 & 3.33 \\
\hline Total & 11 & 100 & 19 & 100 & 15 & 100 & 30 & 100 \\
\hline
\end{tabular}

Table 3: AflatoxinM1 (AFM1) concentrations in examined samples

\begin{tabular}{|llllllll|}
$\begin{array}{l}\text { Samples } \\
\text { types }\end{array}$ & $\begin{array}{l}\text { Samples } \\
\text { number }\end{array}$ & Positive & \multicolumn{2}{c}{ Range $(\mathbf{p p b})$} & $\begin{array}{l}\text { Mean of level } \\
\pm \text { SE }\end{array}$ \\
\hline Raw & 10 & 6 & 60 & 0.013 & 0.125 & $0.061 \pm 0.015$ \\
milk & & & No. & $\%$ & Min & Max & \\
\hline $\begin{array}{l}\text { Milk } \\
\text { powder }\end{array}$ & 10 & 8 & 80 & 0.013 & 0.021 & $0.016 \pm 0.001$ \\
\hline $\begin{array}{l}\text { Roomy } \\
\text { cheese }\end{array}$ & 10 & 8 & 80 & 0.01 & 0.021 & $0.015 \pm 0.001$ \\
\hline $\begin{array}{l}\text { Kariesh } \\
\text { cheese }\end{array}$ & 10 & 6 & 60 & 0.045 & 0.2 & $0.088 \pm 0.024$ \\
\hline Total & 40 & 28 & 70 & 0.01 & 0.2 & $0.041 \pm 0.008$ \\
\hline
\end{tabular}

strain specificity, strain variation and instability of toxigenic properties (Atanda et al., 2011).

A total of 40 samples of milk and dairy products (10 raw milk samples, 10 milk powder, 10 roomy cheese samples, 10 kariesh cheese samples) were examined for presence of AFM1. Aflatoxin M1 (AFM1) was detected in 60\% of raw milk samples, ranging from 0.013 to $0.125 \mathrm{ppb}$ with a mean \pm SE value of $0.061 \pm 0.015 \mathrm{ppb}$. Presence of AFM1 in the milk referred to feeding of animals on aflatoxin B1 (AFB1) containing feed which transformed in liver by hepatic microsomal cytochrome P450 to AFM1 and descend in milk (Frobish, et al., 1986). In addition to, a linear relationship between AFM1 in milk and AFB1 content of feed was reported (Van Egmond, 1989; Wood, 1991). The amount of AFM1 found in milk represents normally 1 to $2 \%$ of the ingested AFB1. However, it can be as high as $6 \%$ in high-producing cows (Veldman et al., 1992).

The Egyptian regulation (Egyptian regulation, 1990) for AFM1 in milk recommended that milk must be free from AFM1, in this study, all the positive samples exceeded the Egyptian regulation, while, EU regulation for AFM1 in milk (EU:European Commission (EC), 2006) recommended a maximum limit for presence of AFM1 in milk should not exceed $0.05 \mu \mathrm{g} / \mathrm{kg}$, so in this study, $66.66 \%$ of the positive raw milk samples exceeded the EU regulation and $33.33 \%$ of these samples complied with it (Table 4). In comparison with FDA regulation (US Food and Drug Administration, 1996), which has a permissible limit of $0.5 \mathrm{ppb}, 100 \%$ of our samples complied with its regulation for AFM1 in milk. 
OPEN OACCESS

Table 4: AFM1 level in positive samples in relation to the permissible limits:

\begin{tabular}{lllll}
$\begin{array}{l}\text { Positive } \\
\text { Samples }\end{array}$ & \multicolumn{2}{l}{$\begin{array}{l}\text { Egyptian regula- } \\
\text { tion,1990 }\end{array}$} & \multicolumn{2}{l}{$\begin{array}{l}\text { EU: European Com- } \\
\text { mission (EC), 2006 }\end{array}$} \\
\cline { 2 - 5 } exceed & comply & Exceed & Comply \\
Raw milk & $100 \%$ & 0 & $66.66 \%$ & $33.33 \%$ \\
\hline Milk powder & $100 \%$ & 0 & 0 & $100 \%$ \\
Roomy cheese & $100 \%$ & 0 & 0 & $100 \%$ \\
\hline Kariesh cheese & $100 \%$ & 0 & $50 \%$ & $50 \%$
\end{tabular}

Concerning to milk powder samples, $80 \%$ of all examined samples were contaminated by AFM1in a range of 0.013 to $0.021 \mathrm{ppb}$ with a mean $\pm \mathrm{SE}$ value of $0.016 \pm 0.001 \mathrm{ppb}$. Presence of AFM1 in milk power may refer to stability of AFM1 in heat treatment and drying as reported in most researches (JECFA, 2001). All the positive milk powder samples exceed the Egyptian regulation and comply with the EU regulation.

In kariesh cheese samples, $60 \%$ of the examined samples were contaminated with AFM1 in a range of 0.045- 0.2 $\mathrm{ppb}$ with a mean $\pm \mathrm{SE}$ value $0.088 \pm 0.024 \mathrm{ppb}$ which $\mathrm{ex}^{-}$ ceeds the Egyptian regulation, while, 50\% only of these samples exceeded the EU regulation. Concerning to roomy cheese samples, $80 \%$ of the examined samples were contaminated with AFM1 in a range of 0.01 to $0.021 \mathrm{ppb}$ with a mean \pm SE value of $0.015 \pm 0.001 \mathrm{ppb}$. All the positive roomy cheese samples exceed the Egyptian regulation, while all of these samples comply with the EU regulation. AFM1may be found in the milk of animals that are fed with aflatoxin B1(AFB1) containing feed (Van Egmond, 1991) or dried milk used to enrich the milk used to make cheese (Blanco et al., 1988), in addition to the stability of aflatoxin M1 during ripening and AFM1 associated with casein, so that cheese curd contains a higher concentration than whey (Yousef and Marth, 1989). Significant differences were detected between concentrations of AFM1 toxin in different milk products $(\mathrm{p}=0.001)$.

OTA was detected also in milk and milk product samples and the results showed that (80\%) of all examined samples were contaminated with OTA in a range of 0.34 to $13 \mathrm{ppb}$ with a mean $\pm \mathrm{SE}$ value of $5.134 \pm 1.822 \mathrm{ppb}$ (Table 5). Presence of OTA in milk in spite of ruminal microflora and protozoa ability of its degradation may refer to change in diet (high concentrate proportion and high feeding levels) which lead to shift in microbial population and higher contamination potential (Mobashar et al., 2010; Özpinar et al., 1999).

In this study, OTA in raw milk samples ranged from 0.34 to $13 \mathrm{ppb}$ with a mean $\pm \mathrm{SE}$ value of $5.134 \pm 1.822 \mathrm{ppb}$. This result is higher than results detected by Coffey et al. (2009) and lower than Breitholtz-Emanuelsson et al. (1993). In milk powder samples, OTA levels were detected in a range of 3.9 to $10 \mathrm{ppb}$ with a mean $\pm \mathrm{SE}$ value of $6.925 \pm 0.848$ $\mathrm{ppb}$ (Table 5). This result is higher than results detected by Kabak (2012). OTA levels were detected in roomy cheese samples in a range of $3-4.8 \mathrm{ppb}$ with a mean $\pm \mathrm{SE}$ value of $3.811 \pm 0.243 \mathrm{ppb}$, this result is nearly similar to Awad et al. (2012). OTA levels were detected in kariesh cheese samples in a range of $2-5.2 \mathrm{ppb}$ with a mean $\pm \mathrm{SE}$ value of $3.137 \pm 0.441 \mathrm{ppb}$. This result is higher than Hussein (2013) Presence of OTA in cheese may refer to use of contaminated milk with toxin carried over from animals fed with contaminated feed (Monaci and Palmisano, 2004) or cheese contamination with OTA producing species as P.verrucosum and P.nordicum (Cabañes et al., 2010).

Table 5: Ochratoxin A (OTA( concentration in different examined samples

\begin{tabular}{|c|c|c|c|c|c|c|}
\hline \multirow{2}{*}{$\begin{array}{l}\text { Samples } \\
\text { types }\end{array}$} & \multirow{2}{*}{$\begin{array}{l}\text { Samples } \\
\text { number }\end{array}$} & \multicolumn{4}{|c|}{ Positive Range (ppb) } & \multirow{2}{*}{$\begin{array}{l}\text { Mean of level } \\
\pm \mathrm{SE}\end{array}$} \\
\hline & & No. & $\%$ & Min & Max & \\
\hline $\begin{array}{l}\text { Raw } \\
\text { milk }\end{array}$ & 10 & 7 & 70 & 0.34 & 13 & $5.134 \pm 1.822$ \\
\hline $\begin{array}{l}\text { Milk } \\
\text { powder }\end{array}$ & 10 & 8 & 80 & 3.9 & 10 & $6.925 \pm 0.848$ \\
\hline $\begin{array}{l}\text { Roomy } \\
\text { cheese }\end{array}$ & 10 & 9 & 90 & 3 & 4.8 & $3.811 \pm 0.243$ \\
\hline $\begin{array}{l}\text { Kariesh } \\
\text { cheese }\end{array}$ & 10 & 8 & 80 & 2 & 5.2 & $3.137 \pm 0.441$ \\
\hline Total & 40 & 32 & 80 & 0.34 & 13 & $4.711 \pm 0.514$ \\
\hline
\end{tabular}

The highest incidence of OTA recorded in roomy cheese may refer to unhygienic conditions in package or storage which facilitate mould growth on cheese surface and subsequently toxin production in favorable conditions. Significant differences were detected between concentrations of OTA in different milk products $(\mathrm{p}=0.037)$. Presence of OTA in high concentration $(0.34-13 \mathrm{ppb})$ with mean $4.711 \pm 0.514 \mathrm{ppb}$ (Table 5), may refer to presence of OTA with high level in animal feed especially that animal feed in Egypt depends on concentrated diet which change OTA degradation ability in rumen. About $35 \%$ of positive samples (that contain different levels of OTA) didn't contain OTA producing moulds, this may refer to disappear of producing mould during processing of dairy products or / and carry over from contaminated animal feed.

In conclusion, Presence of moulds and mycotoxins in milk and different dairy products with high percentage and high levels indicates public health hazards. So strict hygienic conditions in milk production, controlled hygienic conditions in dairy products factories, strict laws that prevent mycotoxin contaminated products reach to consumer, using advanced methods for mycotoxin prevention and control to protect human and animal life in addition to making more researches on mycotoxins and methods of 
their prevention, should be considered.

\section{ACKNOWLEDGMENTS}

Department of Bacteriology, Mycology and Immunology, Faculty of Veterinary Medicine, Mansoura University, Egypt, supported this study.

\section{CONFLICT OF INTEREST}

The authors declare that there is no conflict of interest.

\section{AUTHOR'S CONTRIBUTION}

The 1st author (GY) designed the experiment and revised the manuscript. The 2nd author (DI) collected milk and dairy product samples, carried out the conventional culturing and mycotoxin detection, analyzed data, wrote the paper. The 3rd author (AA) partly wrote the manuscript and took the responsibility of correspondence to the journal. The 4th auhtor (MME) revised the manuscript. All authors approved the final version of the manuscript for publication.

\section{REFERENCES}

-AOAC (1991). AOAC Official Method 991. 31, Aflatoxin in corn, raw peanut and peanut butter using Immunoaffinity column (Aflatest method) with solution fluorometry. J. AOAC Int. 74(1): 81-88.

-APHA (American Public Health Association) (1992). Standard methods for examination of dairy products. I.N.C., $16 \mathrm{ed}$. National academy press, Washington D.C., USA.

-Atanda SA, Pessu, PO, Agoda S, Isong IU, Adekalu OA, Echendu MA and Falade TC (2011). Fungi and mycotoxins in stored foods. African J. Microbiol. Res. 5(25): 4373-4382. http://dx.doi.org/10.5897/AJMR11.487

-Awad, EI, Abdelfattah ME, Abdelkaliek, AA, El-diasty, EM (2012). Prevalence of ochratoxin in small and large scale produced roomy cheese in Sharkia Governorate. World Rural Observ. 4(3): 76-80.

-Barrios MT, Medina LM, Cordoba MG, Jordano R (1997). Aflatoxin producing strains of Asperigillus flavus isolated from cheese. J. Food Prot. 60: 192-194.

-Bayman P, Baker JL (2006). Ochratoxins: A global perspective. Mycopathologia. 162: 215-223. http://dx.doi.org/10.1007/ s11046-006-0055-4

-Bille PG, Haradoeb BR, Shigwedha N (2009). Evaluation of chemical and bacteriological quality of raw milk from Neudamm dairy farm in Namibia. African J. Food Agr. Nutr. Develop. 9(7): 1511-1523.

-Blanco JL, Domingues L, Gomez-lucia E, Garayzabal JFF, Goyache J, Suarez G (1988). Behavior of aflatoxin during the manufacture, ripening and storage of Manchegotype cheese. J. Food Sci. 53: 1373-1376. http://dx.doi. org/10.1111/j.1365-2621.1988.tb09280.x

-Bonfoth B (2004). Sources of contamination of local milk and methods to improve its microbiological quality. Bamako
(Mali). Sahelian Stud. Res. Pp. 89.

-Boudra H, Morgavi DP (2006). Development and validation of a HPLC method for the quantitation of ochratoxins in plasma and raw milk. J. Chromat. B. 843: 295-301. http:// dx.doi.org/10.1016/j.jchromb.2006.06.018

- Boudar H, Barnouin J Dragacci S, Morgavi DP (2007). Aflatoxin M1 and Ochratoxin A in raw bulk milk from French dairy herds. J. Dairy Sci. 90: 3197-3201. http:// dx.doi.org/10.3168/jds.2006-565

-Breitholtz-Emanuelsson A, Olsen M, Oskarsson A, Palminger I, Hult K (1993). Ochratoxin A in cow's milk and in human milk with corresponding human blood samples. J. AOAC Int. 76(4):842-846

-Brown RL, Chen ZY, Menkir A, Cleveland TE, Cardwell K, Kling J (2001). Resistance of aflatoxin accumulation in kernels of maize in breeds selected for ear rot resistance in West and Central Africa. J. Food Prot. 64: 396-400.

-Bullerman LB (1979). Significance of mycotoxins to food safety and human health. J. Food Prot. 42(1): 65-68.

-Cabañes FJ, Bragulat MR, Castellā G (2010). Ochratoxin A producing species in the genus penicillium. Toxins (Basel). 2(5):1111-1120. http://dx.doi.org/10.3390/toxins2051111

- Chapman HR, Sharpe ME (1990). Microbiology of cheese. In: Dairy Microbiology (Ed.: Robinson, R.K.), London and New Jersey, Applied Science Publishers. Pp. 203-290.

- Coffey R Cummins E and Ward S (2009). Exposure assessment of mycotoxins in dairy milk. Food Control. 20(3): 239-249. http://dx.doi.org/10.1016/j.foodcont.2008.05.011

-Commission Regulation (2004). (EC) 2004 No 683/2004 of 13 April 2004 amending Regulation (EC) No 466/2001 as regards aflatoxins and ochratoxin $\mathrm{A}$ in foods for infants and young children- OJEU L 106 3-5.

- Creppy EE (2002). Update of survey, regulation and toxic effects of mycotoxins in Europe. Toxicol. Letters. 127: 19-28. http://dx.doi.org/10.1016/S0378-4274(01)00479-9

-Cross S (1997). Mold spores: The unusual suspects in hay fever. Commun. Nurse. 3(4):25-26.

-Desmasures N Bazin F, Guèguen M (1997). Microbiological composition of raw milk from selected farms in the Camembert region of Normandy. J. Appl. Microbiol. 83:5358. http://dx.doi.org/10.1046/j.1365-2672.1997.00166.x

-D'Mello JPF, MacDonald AMC (1997). Mycotoxins. Anim. Feed Sci. Technol. 69: 155-166. http://dx.doi.org/10.1016/ S0377-8401(97)81630-6

-Egyptian regulation (1990). Maximum limits for mycotoxin in food. Part L. Aflatoxins E.s. 1875-1990. Egyptian organization for standardization and quality control.

-Egyptian standards (E.S) (2005). ES: 1648/2005, milk and dairy products part 1: milk powder, Egyptian Organization for Standardization and Quality control.

-Egyptian standards (E.S) (2005). ES: 1007-1/2005, milk and dairy products part 1:hard cheese, Egyptian Organization for Standardization and Quality control.

-Egyptian standards (E.S) (2005). ES: 1008-1/2005, milk and dairy products part 1: softcheese, Egyptian Organization for Standardization and Quality control.

-El-Diasty EM, Salem RM (2008). Incidence of lipolytic and proteolytic fungi in some milk products and their public health significance. Arab J. Biotech. 12 (1):49-56.

-El-Fadaly HM, El-Kadi SM, Hamad , Habib AA (2015). Isolation and Identification of Egyptian Ras Cheese (Romy) Contaminating Fungi during Ripening Period. J. Microbiol. Resh. 5(1):1-10. 
-El-Shazly ES (2002). Studies on enterobactreace, yeasts and moulds in milk and dairy products. Ph.D thesis, Fac. Vet. Med. Monofea Univ. Egypt.

-EU: European Commission (EC) (2006). Commission Regulation. 1881/2006 of December 12th setting maximum levels of certain contaminants in foods. Official Journal of European Communities L 364/5.

-FAO (2001). FNP73, Manual of the application of HACCP system in mycotoxin prevention and control. FAO Food and Nutrition paper no. 73, FAO, Rome.

- Frobish RA, Bradley BD, Wagner DD, Long-Bradley PE, Hairstone $H$ (1986). Aflatoxin residues in milk of dairy cows after ingestion of naturally contaminated grain. J. Food Prot. 49: 781-785.

-Hussein S (2013). Prevalence of mycotoxin residues in soft cheese. Faculty of Vet. Med. Zagazig University (master's degree thises).

-ICMSF (1996). Toxigenic fungi: Aspergillus. In: Roberts TA, Baird-Parker AC, Tompkin RB, editors. Microorganisms in foods 5: microbiological specifications of food pathogens. International Commission on Microbiological Specifications for Foods. London, UK: Blackie Academic and Professional. An Imprint of Chapman \& Hall. Pp. 347-81.

-Iha MH, Barbosa CB, Heck AR, Trucksess M W (2014). Aflatoxin M1 and ochratoxin A in human milk in Ribeirão Preto-SP, Brazil. Food Control. 40: 310-313. http://dx.doi. org/10.1016/j.foodcont.2013.12.014

-JECFA (2001). Safety evaluation of certain mycotoxins in food -prepared by the 56th meeting of the JECFA (Joint FAO/ WHO Expert Committee on Food Additives) - FAO Food and Nutrition Paper 74/WHO Foods Additives Series 47.

-Kabak B (2012). Aflatoxin M1 and ochratoxin A in baby formulae in Turkey: Occurrence and safety evaluation. Food Control. 26: 182-187. http://dx.doi.org/10.1016/j. foodcont.2012.01.032

-Köppen R, Koch M, Siegel D, Merkel S, Maul R, Nehls I (2010). Determination of mycotoxins in foods: current state of analytical methods and limitations. Appl. Microbiol. Biotechnol. 86:1595-1612. http://dx.doi.org/10.1007/ s00253-010-2535-1

- Kure CF, Skaar I, BrendehaugJ (2004). Mould contamination in production of semi-hard cheese.Intern.J.Food Microbiol.93: 41-49. http://dx.doi.org/10.1016/j.ijfoodmicro.2003.10.005

- Magan N (2006). Mycotoxin contamination of food in Europe: Early detection and prevention strategies. Mycopathologia. 262: 245-253. http://dx.doi.org/10.1007/s11046-0060057-2

-Mobashar M, Hummel J, Blank R, Südekum KH (2010). Ochratoxin $\mathrm{A}$ in ruminants-a review on its degradation by gut microbes and effects on animals. Toxins (Basel). 2(4): 809-39. http://dx.doi.org/10.3390/toxins204809

- Monaci L, Palmisano F (2004). Determination of ochratoxin A in foods: State-of- art and analytical challenges. Anal. Bio-anal. Chem. 378: 96-103. http://dx.doi.org/10.1007/ s00216-003-2364-5

- Mounier J, Goerges S, Gelsomino R, Vancanneyt M, Vandemeule-broecke K, Hoste B (2006). Sources of the adventitious microflora of a smear-ripened cheese. J. Appl. Microbiol. 101:668-681. http://dx.doi.org/10.1111/j.13652672.2006.02922.x

- Muscarella M, Palermo C, Rotunno T, Quaranta V and D'Antini P (2004). Survey of Ochratoxin A in cereals from Puglia and Basilicata. Veterinary Research
Communications. 28: 229-232. http://dx.doi.org/10.1023/ B:VERC.0000045413.49671.97

- Ozpinar H, Augonyte G, Drochner W (1999). Inactivation of ochratoxin in ruminal fluid with variation of $\mathrm{pH}$-value and fermentation parameters in an in vitro system. Environ. Toxicol. Pharmacol. 7: 1-9. http://dx.doi.org/10.1016/ S1382-6689(98)00041-6

-Pitt JI (1984). The significance of potentially toxigenic fungi in foods. Food Tech. in Australia. 36(5):218-219 Cited in FSTA (1985). Vol. 17, No. 12.

-Pitt JI, Hocking AD (1997).Fungi and food spoilage, $3^{\text {rd }}$ edition. Springer Dordrecht Heidelberg, London, New York. http:// dx.doi.org/10.1007/978-1-4615-6391-4

-Pitt JI, Hocking, AD, Samson RA, King AD (1992). Recommended methods for mycological examination of foods, 1992. In Modern methods in food Mycology, eds. R.A. Samson, A. D. Hocking, J. I. Pitt and A. D. King, Amesterdam: El sevier. Pp. 365-368.

-Sabreen MS, Zaky ZM (2001). Incidence of aflatoxigenic moulds and aflatoxins in cheeses. $1^{\text {st }}$ Cong. Of Food Hygiene \& Human Health, 6-8 February 2001. Dept. of Food Hyg. Fac, Vet. Med. Assiut Univ. Egypt.

-Samson RA, Hoekstra ES, Frisvad JC, Smith M (1988). Introduction to food-borne Fungi, $2^{\text {nd }}$ ed. Centraalbureau voor Schimmelcultures, Baarn, Delft, the Netherlands.

-Scott MP (2002). Methods of analysis for ochratoxin A. Mycotoxins and Food Safety, 117-134. http://dx.doi. org/10.1007/978-1-4615-0629-4_12

-Scott PM,Trucksess MW (1997).Application of immunoaffinity columns to mycotoxin analysis. J. AOAC Int. 80: 941-949.

-Sengun I, Yaman D, Gonul S (2008). Mycotoxins and mould contamination in cheese. World Mycotox. J. 3: 291-298. http://dx.doi.org/10.3920/WMJ2008.x041

-SPSS (2004). Statistical Package for Social Sciences release version 16.0. SPSS inc. USA.

-Tasci F (2011). Microbiological and chemical properties of raw milk consumed in Burdur. J. Anim.Vet. Adv. 10(5):635-641. http://dx.doi.org/10.3923/javaa.2011.635.641

-US Food and Drug Administration (1996). Sec. 527. 400 Whole Milk, Low Fat Milk, Skim Milk-Aflatoxin M1 (cpg 7106.210). FDA Compliance Policy Guides (Washington, DC: FDA). Pp. 219.

-Van Egmond HP (1989a). Current situation on regulations for mycotoxins. Overview of tolerance and status of standard methods of sampling and analysis. Food Addit.Contam. 6:139-188. http://dx.doi.org/10.1080/02652038909373773

-Van Egmond HP (1989b). Introduction. In: van Egmond, H.P. (Ed.), Mycotoxins in Dairy Products. Elsevier Applied Science, London and New York. Pp. 1-10.

-Van Egmond HP (1991). Mycotoxins Inter. Dairy Fed. 9101:131-145.

-Veldman A, Meijs JAC, Borggreve GJ, Heeres van der Tol JJ (1992). Carry-over of aflatoxin from cows' food to milk. Anim. Prod. 55:163-168. http://dx.doi.org/10.1017/ S0003356100037417

-Wood GE (1991). Aflatoxin M1, mycotoxins and phytoalexins (Pp. 145-163). London: CRC.

-Yousef AE, Marth EH (1989). Stability and degradation of aflatoxin M1. In: Van Egmond, H.P. (Ed.), Mycotoxins in dairy products.Elsevier Applied Science, London and New York. Pp. 127-161.

-Zain ME (2011). Impact of mycotoxins on humans and animals. J. Saudi Chem. Soc. 15: 129-144. http://dx.doi. 
org/10.1016/j.jscs.2010.06.006

-Zerfiridis GK (1985). Potential aflatoxin hazards to human health from direct mold growth on Teleme cheese. J. dairy Sci. 68(9): 2184-2188. http://dx.doi.org/10.3168/jds. S0022-0302(85)81089-4
-Zheng Z, Hanneken J, Houchins D, King RS, Lee P,Richard JL (2005). Validation of an ELISA test kit for the detection of ochratoxin A in several food commodities by comparison with HPLC. Mycopathologia. 159: 265-272. http://dx.doi. org/10.1007/s11046-004-8663-3 